\title{
Rationality in the Use of Non Renewable Natural Resources in Agriculture
}

\author{
Rogério de Paula Lana \\ Universidade Federal de Viçosa \\ Brazil
}

\section{Introduction}

The increase in human population and the demand for life quality have induced the growing production of food and alternative vegetal energy sources in replacement to petrol. Soybean responds to more than $80 \%$ of biodiesel production, and will reach $5 \%$ inclusion in the fossil diesel in the next years in Brazil. This trend will increase pressure to new areas for soybean production on actually human food production areas, as well on pasture and untouched forests areas.

The progress of agriculture has been based on increase in animals and plants productivity per unit of area, which only has application when land availability is the sole limiting factor. However, the efficiency of use of limiting resources (including water, fertilizers and petrol) has to be considered. This mistaken vision is leading to excessive use of non renewable natural resources and environmental pollution. The reserves of phosphate in the world that can be explored at low cost are enough for 40 to 100 years and the world reserves of potassium are enough for 50 to 200 years. The situation is worse for micronutrients, in which the reserves of copper and zinc are enough for 60 years, manganese for 35 years and selenium for 55 years (Herring \& Fantel, 1993; Roberts \& Stewart, 2002; Aaron, 2005).

In addition to the depletion of natural reserves, the excessive use of fertilizers can contribute to soil and water courses contamination with nitrate (Angus, 1995; Bumb, 1995), soil acidification (Helyar \& Poter, 1989), and emissions of carbon dioxide $\left(\mathrm{CO}_{2}\right)$, nitrous oxide $\left(\mathrm{N}_{2} \mathrm{O}\right)$ and ammonia to the atmosphere. The pollution with nitrate has being an actual preoccupation in Europe and North America. The fertilization with phosphorus and nitrogen cause decrease in water oxygenation by excessive increase in the population of toxic algae in the oceans (Kebreab et al., 2002).

The agriculture participates in $20 \%$ of annual increase in the anthropogenic emission of greenhouse gases, mainly $\mathrm{CH}_{4}$ and $\mathrm{N}_{2} \mathrm{O}$. Approximately $70 \%$ of all anthropogenic emission of $\mathrm{N}_{2} \mathrm{O}$ is attributed to agriculture. The current methodology used in Canada to estimate the flow of $\mathrm{N}_{2} \mathrm{O}$ is based in the direct relation between the emission of $\mathrm{N}_{2} \mathrm{O}$ and the application of nitrogen fertilizers (Lemke et al., 1998).

The possible deleterious effects of emissions of $\mathrm{N}_{2} \mathrm{O}$ are global warming and catalytic destruction of the ozone chain in the stratosphere, in which the $\mathrm{N}_{2} \mathrm{O}$ retains 13 times more heat than methane $\left(\mathrm{CH}_{4}\right)$ and 270 times more than $\mathrm{CO}_{2}$ (Granli \& Bockman, 1994). The atmospheric level of $\mathrm{N}_{2} \mathrm{O}$ has increased in growing fashion since 1960, associated with increase in utilization of nitrogen fertilizers (Bumb, 1995; Strong, 1995). 


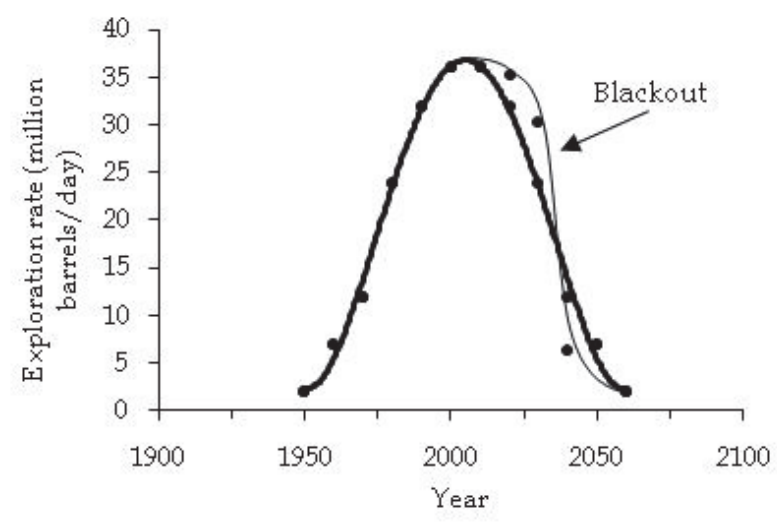

Fig. 1. Hubbert curve of exploration of petrol (non renewable natural resource), and altered curve by artificial maintenance of peak of production.

An worried phenomena about the use of non renewable natural resources can be visualized in the Hubbert curve (by Dr. Marion King Hubbert), which was a Shell Geologist, who predicted in 1956 that the global production of petrol would present a peak in the beginning of the XXI century (Hubbert Peak theory, accessed in March 02, 2009), and the curve of exploration follows the bell shape (Figure 1).

The phenomena observed by Hubbert related to petrol exploration is applicable to any other limiting natural resource, such as fertilizers, soil, and water and, consequently, food production. As more persistent is the maintenance of the maximum exploration of a resource, more drastic is the fall in the exploration of the final reserves in a short space of time, occurring the called blackout or sharply decay in the rate of production (Figure 1). Therefore, after the peak of exploration, if there is no new reserves to be discovered, no alternatives to produce more food without dependence on the available resources, or control of excessive exploration based on efficiency of use of these resources, catastrophic consequences can occur with mankind in some time of this century, as predicted by the Club of Rome in 1972, in the known publication "The limits of growth" (Meadows et al., 1972). The alert of the Club of Rome was based in the model associating accelerated industrialization, rapid population growth, depletion of non renewable natural resources, widespread malnutrition, and environmental pollution.

The objective of this work is to demonstrate the application of saturation kinetic models to improve efficiency of use of non renewable natural resources in agriculture, avoid the complete depletion as predicted by the Hubbert curve, and minimize the problems related to environmental pollution.

\section{Population growth curve}

The growth curve of populations of life beings in the absence of factors that affects the physical integrity, such as sickness and predation, has sigmoid curve (Gompertz or hyperbolic curve), including latency, exponential growth, plateau and senescence or death. The plateau occurs due to the saturation phenomena associated with depletion of nutrients or in some cases by environmental pollution, which acts in feedback against the uncontrolled growth (Figure 2). 


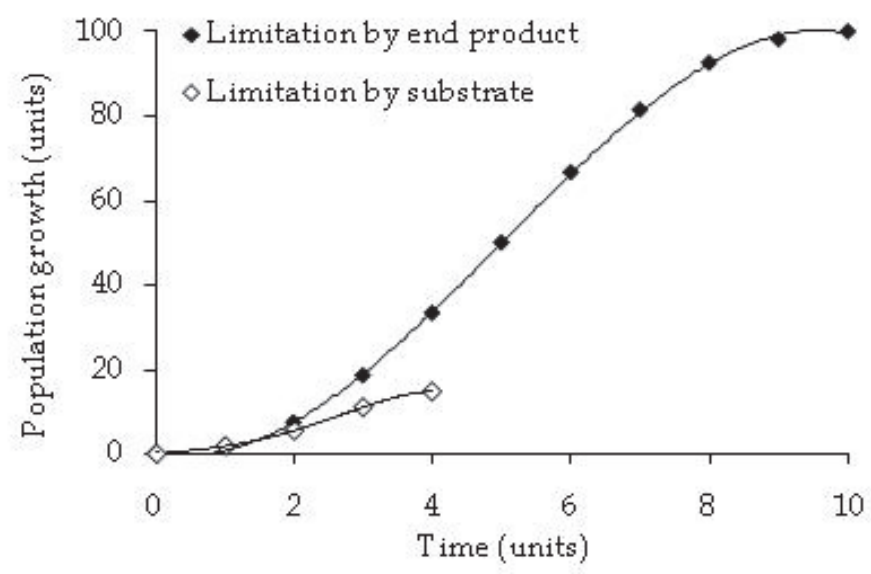

Fig. 2. Theoretical growth curve of life beings as a function of saturation by limitation of nutrients (under nutrition) or by products of metabolism (environmental pollution).

As an example, a bacterium with volume of $1 \mu \mathrm{m}^{3}$ and duplication time of 20 minutes has potential to reach a biomass much greater than the earth in only 48 hours or 144 generations (Russell, 2002; p.57-58). Therefore, the archaea and bacteria are the first life beings of the planet, are hungry most of time, and can be the survivors of a biological collapse, such as those that occurred 65,000,000 years ago with the dinosaurs and 250,000,000 years ago, when more than $90 \%$ of life beings were extinct, leading to the formation of petrol reservoirs that are being explored actually.

Another example of cessation of growth and death of population by environmental pollution is in the silage production, where the bacteria die and the nutrients are conserved to be used by ruminants, as a consequence of the acidity caused by accumulation of fermentation end products - the volatile fatty acids.

Speaking of food production crisis lead we back to the Malthus theory, which although there are some conceptual errors, it will threaten the humanity and all life beings forever. According to Malthus, the population growth curve follow geometric progression and the food production arithmetic progression, leading to the crisis of food supply in some situations or in some periods of our existence (Thomas Malthus, accessed in March 02, 2009).

However, both population growth and food production follow a sigmoid curve up to the plateau or in form of a bell or double sigmoid over time (the second goes down hill, similar to the first in a mirror). The population growth curve is cumulative, as a consequence of the sum of the annual growth rates (Figure 3), which depend on the annual rate of food production (productivity), that by its time is consequence of the annual rate of soil utilization and exploration of non renewable natural resources (fertilizers and petrol), that follow the Hubbert curve. Changes in these curves can be caused by men or naturally, with discoveries of new food production technologies, population death (caused by diseases, wars, predations, among others), proliferation of plagues and diseases in plants, climatic changes, among others. 


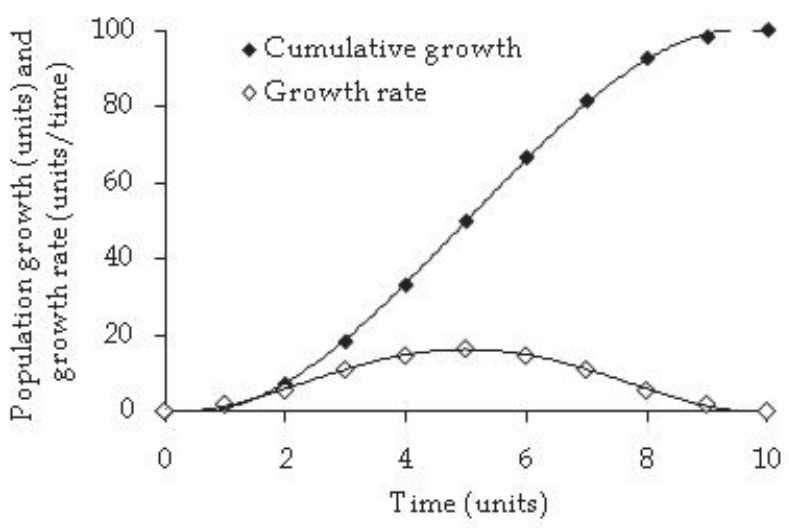

Fig. 3. Theoretical population growth (cumulative and growth rate) as function of time.

Studies of these phenomena lead us to understand the need for rational use of non renewable natural resources. The kinetic saturation models are important tools generated by science in order to evaluate the efficiency and allow the rational use of non renewable natural resources (Lana, 2005; Lana et al., 2005; Lana, 2007a,b; Lana et al., 2007a,b; Lana, 2008). As a result, they can avoid the complete depletion of the resources and the collapse in food and energy supply, with dramatic consequences for our civilization, as predicted by Malthus, Hubbert and Club of Roma.

\section{Models of biological responses to nutrients}

The first studies on the limiting factors in the plants growth were developed by Carl Sprengel in 1826 and 1828, and by Liebig in 1840, leading to the rejection of humus theory and formulation of Law of minimum (van der Ploeg et al., 1999). The Law of minimum or Law of response is associated with the absence of nutrient replacement, linear response in production by increase in the quantity of the limiting factor and a maximum plateau of response, in which the plants do not respond satisfactorily anymore to the limiting nutrient.

A posterior mark was the Law of diminishing return of Mitscherlich (1909). The convex exponential equation of Mitscherlich, with a model that includes the maximum asymptotic yield, allows calculating the optimum economic level of fertilization, based in the benefitcost ratio.

The Michaelis-Menten model (Michaelis \& Menten, 1913) was developed to describe the enzymatic kinetic in the beginning of the 20 century. The Lineweaver-Burk model (Lineweaver \& Burk, 1934), an equation of the linear regression of the reciprocal of $Y$ (enzymatic activity) as a function of the reciprocal of $X$ (concentration of substrate), was used to obtain the kinetic constants of the Michaelis-Menten model: $\mathrm{k}_{\mathrm{s}}$ (the amount of substrate needed to reach half of maximum enzymatic activity) and $\mathrm{k}_{\max }$ (maximum enzymatic activity).

Later, researchers verified that the microbial growth rate was dependent of substrate concentration and both were related to the saturation kinetic typical of enzymatic systems (Monod, 1949; Russell, 1984). 
Although the use of saturation kinetic model to explain the nutrients responses by the superior forms of life is not being adopted (Morgan et al., 1975), the Michaelis-Menten model allows to explain the curvilinear relationship of plants and animals to the nutrients and the model of Lineweaver-Burk allows to obtain the kinetic constants, $\mathrm{k}_{\mathrm{s}}$ (the amount of substrate needed to reach half theoretical maximum response in rate of growth or production of milk, wool, eggs, among others) and $\mathrm{k}_{\max }$ (theoretical maximum response in rate of growth or production), according to Lana et al. (2005).

The responses of plants and animals to nutrients as saturation phenomena have important implications in addition to calculation of the rate of decreasing economical return and estimates of nutrients recommendations, such as the consciousness about the excessive use of non renewable natural resources; soil, water, and air pollution; and global warming.

The knowledge about the efficiency of utilization of fertilizers in agriculture will play an important role in the political decisions about the rational use of non renewable natural resources in the future. The natural fertilizer sources have to be used with maximum efficiency and with minimum negative effects in the environment.

\section{Marginal response or Law of diminishing return in plants}

Recommendations of fertilization are mostly based in the method of calculation of nutrients requirements of a culture and the mineral contribution of the soil. The fertilizers are then calculated to supply the deficiencies. This method allows recommendation of the lower level that maximize the production. However, the method does not indicate changes in the recommendation based on changes in the costs of nutrients and grains. Also, it does not give direct information of the effect of application of other level than the recommended one (Makowski et al., 1999).

It has being utilized a variety of empirical models to predict the responses to nutrients and to calculate the optimum levels of nutrients. Among then, it is included the model of Mitscherlich, square root (Mombiela et al., 1981; Sain \& Jauregui, 1993), exponential, linearplus-plateau, linear-plus-hyperbola, quadratic and quadratic-plus-plateau (Cerrato \& Blackmer, 1990; Bullock \& Bullock, 1994; Makowski et al., 1999, 2001).

The use of saturation kinetics to explain the nutritional responses to nutrients by superior life beings are rarely employed (Morgan et al., 1975). The model of Michaelis-Menten has not being evaluated to make recommendations of fertilization. This model has a great potential in recommendation of use of nutrients in agriculture, by considering the efficiency of use of nutrients and the Law of diminishing return, as observed by Mitscherlich (1909). This model can aggregate important concepts such as responses to different levels of nutrients, benefit-cost ratio, efficiency of use of nutrients, rationality of use of non renewable natural resources and consciousness about environmental pollution.

Linear regressions of reciprocal of plants responses as a function of reciprocal of nutrients supply, methodology known as data transformation of Lineweaver-Burk (Lineweaver \& Burk, 1934; Champe \& Harvey, 1994), were proposed by Lana et al. (2005) as follow:

$$
1 / Y=a+b *(1 / X)
$$

where:

$\mathrm{Y}=$ responses of plants (grain yield, $\times 1,000 \mathrm{~kg} / \mathrm{ha}$ ),

$\mathrm{a}=$ intercept, 
$\mathrm{b}=$ coefficient of linear regression,

$\mathrm{X}=$ amount of nutrient $(\mathrm{kg} / \mathrm{ha} /$ year $)$.

The theoretical maximum grain production $\left(\mathrm{k}_{\max }\right)$ is obtained by the reciprocal of intercept $(1 / a)$. The amount of nutrient $(X)$ needed to reach half of theoretical maximum response $\left(k_{s}\right)$ is obtained by the model presented above, replacing $\mathrm{Y}$ by $1 / \mathrm{a} \times 50(\%) \times 0.01$, or dividing the coefficient of the linear regression by the intercept $(b / a)$.

The efficiency of use of fertilizers is calculated dividing the accretion in grain production $\left(\mathrm{Y}_{2}-\mathrm{Y}_{1}\right)$ by the accretion in fertilization $\left(\mathrm{X}_{2}-\mathrm{X}_{1}\right)$, from a specific level of fertilizer in relation to the previous level.

Simulations of biological responses to nutrients in the absence or presence of a second limiting nutrient are presented in Table 1 and Figure 4, in which are expected changes in the maximum yield $\left(\mathrm{k}_{\max }\right)$ and $\mathrm{k}_{\mathrm{s}}$ of the first limiting nutrient (increase, no effect or decrease). The Figure 4A illustrates four kind of responses in production and models of doublereciprocal are presented in Table 1 and Figure 4B, demonstrating the combination of two values of $\mathrm{k}_{\max }$ by two of $\mathrm{k}_{\mathrm{s}}$.

The best effects that a second limiting nutrient can cause are by increasing $\mathrm{k}_{\max }$, decreasing $\mathrm{k}_{\mathrm{s}}$, or both changes that is even better. However, the most common kind of response is by increasing both $\mathrm{k}_{\max }$ and $\mathrm{k}_{\mathrm{s}}$. Increase in $\mathrm{k}_{\max }$ by increase in productivity with a second nutrient lead to increase the efficiency of use of the first limiting nutrient (Figure 4C), but this benefit decreases sharply by increase in the amount of the first limiting nutrient, especially when $\mathrm{k}_{\mathrm{s}}$ is low.

\begin{tabular}{ccccccc}
\hline Equation & Symbol & Intercept $(\mathrm{a})$ & Coefficient $(\mathrm{b})$ & $\mathrm{r}^{2}$ & $\mathrm{k}_{\mathrm{s}}$ & $\mathrm{k}_{\max }$ \\
\hline 1 & $\mathrm{O}$ & 0.8163 & 79.789 & 1.00 & 98 & 1.2 \\
2 & $\triangle$ & 0.9195 & 39.591 & 1.00 & 43 & 1.1 \\
3 & $\square$ & 0.4082 & 39.894 & 1.00 & 98 & 2.4 \\
4 & $\diamond$ & 0.4768 & 19.483 & 1.00 & 41 & 2.1 \\
\hline
\end{tabular}

Table 1. Constants of linear regression of reciprocal of grain production $(x 1,000 \mathrm{~kg} / \mathrm{ha})$ as a function of reciprocal of amount of fertilizers $(\mathrm{kg} / \mathrm{ha} /$ year $)$ in hypothetic situations of high or low values of the saturation constants $\mathrm{k}_{\mathrm{s}}$ ( $\mathrm{kg}$ of fertilizer/ha) and $\mathrm{k}_{\max }(\mathrm{x} 1,000 \mathrm{~kg} / \mathrm{ha})$ see Figure 4B

The plants responses to fertilization depend on soil fertilization, in which high responses occur when soil fertility is low (Figure 5A) and in low level of fertilization, that is the main factor that affects the efficiency of use of fertilizers (Figure 5B).

Equations of data transformation of Lineweaver-Burk were used to explain the effect of fertilization and the effect of a second factor in the yield, $k_{s}, k_{\max }$ and efficiency of use of fertilizers in soybean, bean, wheat and cotton production (Tables 2, 3 and 4).

When limestone was the second factor, there was change in $\mathrm{k}_{\mathrm{s}}$ and $\mathrm{k}_{\max }$ in 34 and 85\%; -75 and $-10 \%$; and 33 and $22 \%$ for soybean fertilized with $\mathrm{P}_{2} \mathrm{O}_{5}$ (Table 2). Limestone as a second factor changed $\mathrm{k}_{\mathrm{s}}$ and $\mathrm{k}_{\max }$, respectively, in -55 and $-12 \%$ for wheat fertilized with $\mathrm{P}_{2} \mathrm{O}_{5}$, and in 9 to $87 \%$ in cotton fertilized with $\mathrm{K}_{2} \mathrm{O}$.

As seen above, increase or decrease in $k_{\max }$ is associated with the same effect in $k_{s}$, but increase in $k_{\max }$ associated with exaggerated increase in $\mathrm{k}_{\mathrm{s}}$ is not desirable because it requires more fertilizer to reach the plateau. In other words, the greater values of $\mathrm{k}_{\mathrm{s}}$ present greater response to the use of fertilizers in high level of fertilization, but it cannot be advantageous due to the increase in the cost of fertilization. 

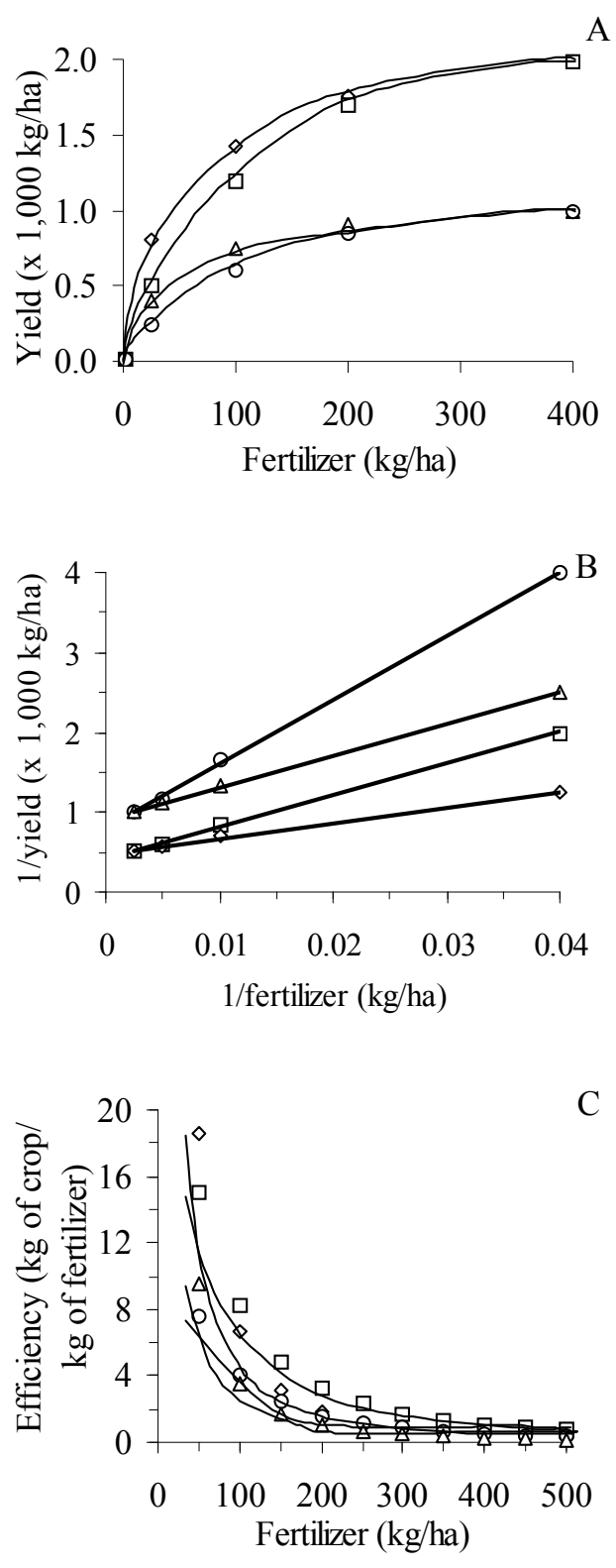

Fig. 4. Biological responses to nutrients as a function of a second limiting nutrient (A) control $(\mathrm{O})$, decrease in $\mathrm{k}_{\mathrm{s}}(\triangle)$, increase in $\mathrm{k}_{\max }(\square)$ and decrease in $\mathrm{k}_{\mathrm{s}}$ and increase in $\mathrm{k}_{\max }$ $(\diamond)$; reciprocal of production as a function of reciprocal of fertilizer level - plot of Lineweaver-Burk (B); and effect of a second limiting nutrient in the efficiency of use of the first one $(\mathrm{C})$ 

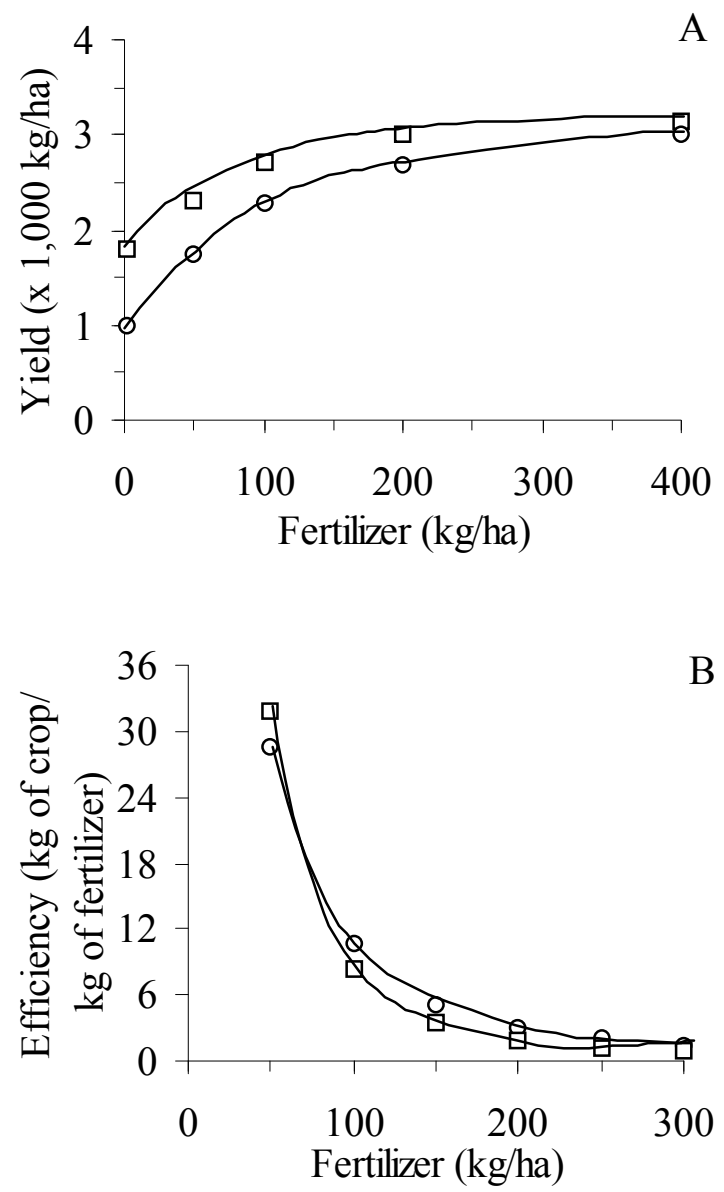

Fig. 5. Plants responses to fertilizers in low $(\mathrm{O})$ and high $(\square)$ soil fertility (A); and the effect of soil fertility in the efficiency of use of fertilizer (B)

In the case of soybean (Table 2), considering US $\$ 1.208 / \mathrm{kg}$ of $\mathrm{P}_{2} \mathrm{O}_{5}$ and US\$0.178/ $\mathrm{kg}$ of soybean, it is necessary $6.8 \mathrm{~kg}$ of soybean to pay $1 \mathrm{~kg}$ of fertilizer. Therefore, it is viable to use 50 to $100 \mathrm{~kg}$ of $\mathrm{P}_{2} \mathrm{O}_{5}$ in the absence of limestone and $100 \mathrm{~kg}$ of $\mathrm{P}_{2} \mathrm{O}_{5}$ in the presence of limestone. Above $150 \mathrm{~kg}$ of $\mathrm{P}_{2} \mathrm{O}_{5}$, although in some cases there was still response to fertilizer, especially in high values of $\mathrm{k}_{\mathrm{s}}$, the response is not viable economically.

In bean production (Table 3), the second factor $\left(\mathrm{P}_{2} \mathrm{O}_{5}\right)$ increased the $\mathrm{k}_{\max }$ of nitrogen from 0.1-0.5 to $1.0-1.6 \times 1,000 \mathrm{~kg} / \mathrm{ha}$ of bean, but also increased the $\mathrm{k}_{\mathrm{s}}$ (1 to 13 and 17 to $29 \mathrm{~kg} / \mathrm{ha}$ of nitrogen). When the second factor was nitrogen, this increased the $\mathrm{k}_{\max }$ of $\mathrm{P}_{2} \mathrm{O}_{5}$ from 0.70.8 to $1.5 \times 1,000 \mathrm{~kg} / \mathrm{ha}$ of bean, but also increased the $\mathrm{k}_{\mathrm{s}}$ (5 to 15 and 136 to $199 \mathrm{~kg} / \mathrm{ha}$ of $\mathrm{P}_{2} \mathrm{O}_{5}$ ). In the second case, the high values of $\mathrm{k}_{\mathrm{s}}$ for $\mathrm{P}_{2} \mathrm{O}_{5}$ caused low improvement in the efficiency of use of this fertilizer in low level of fertilization (Table 4). The extra production in this case cannot be enough to pay the extra amount of fertilizers. 


\begin{tabular}{|c|c|c|c|c|c|c|c|c|}
\hline Product & $\begin{array}{l}\text { Fertilizer } \\
\text { (kg/ha/year) }\end{array}$ & $\begin{array}{l}\text { Second } \\
\text { factor }{ }^{1}\end{array}$ & $\begin{array}{l}\text { Intercept } \\
\text { (a) }\end{array}$ & $\begin{array}{l}\text { Coefficient } \\
\text { (b) }\end{array}$ & $\mathrm{r}^{2}$ & $\mathrm{k}_{\mathrm{s}}{ }^{2}$ & $\mathrm{k}_{\max }{ }^{3}$ & $\begin{array}{l}\text { Source } \\
\text { of data } \\
4\end{array}$ \\
\hline \multirow[t]{2}{*}{ Soybean } & $\mathrm{P}_{2} \mathrm{O}_{5}$ & - & 0.7536 & 57.766 & 1.00 & 77 & 1.3 & 1 \\
\hline & & + & 0.4096 & 42.198 & 1.00 & 103 & 2.4 & 1 \\
\hline \multirow[t]{2}{*}{ Soybean } & $\mathrm{P}_{2} \mathrm{O}_{5}$ & - & 0.3502 & 30.524 & 0.98 & 87 & 2.9 & 2 \\
\hline & & + & 0.3801 & 8.2987 & 0.99 & 22 & 2.6 & 2 \\
\hline \multirow[t]{2}{*}{ Soybean } & $\mathrm{P}_{2} \mathrm{O}_{5}$ & - & 0.3103 & 3.6726 & 0.68 & 12 & 3.2 & 2 \\
\hline & & + & 0.2535 & 3.9962 & 0.53 & 16 & 3.9 & 2 \\
\hline \multirow[t]{2}{*}{ Wheat } & $\mathrm{P}_{2} \mathrm{O}_{5}$ & - & 0.4169 & 174.48 & 1.00 & 419 & 2.4 & 1 \\
\hline & & + & 0.4781 & 91.00 & 1.00 & 190 & 2.1 & 1 \\
\hline \multirow[t]{4}{*}{ Cotton } & $\mathrm{K}_{2} \mathrm{O}$ & - & 0.622 & 4.6865 & 0.91 & 7.5 & 1.6 & 1 \\
\hline & & + & 0.3284 & 2.7052 & 0.97 & 8.2 & 3.0 & 1 \\
\hline & Fertilizer & \multicolumn{7}{|c|}{ Efficiency of use of fertilizers (kg of grains $/ \mathrm{kg}$ of fertilizer) ${ }^{5}$} \\
\hline & (kg/ha) & 502 & 100 & $150 \quad 2$ & 200 & 250 & & 300 \\
\hline \multirow[t]{2}{*}{ Soybean } & $\mathrm{P}_{2} \mathrm{O}_{5}-\operatorname{Lim}^{1}$ & 10.0 & 4.5 & 2.5 & 1.6 & 1.1 & & 0.8 \\
\hline & $+\operatorname{Lim}$ & 16.0 & 8.1 & 4.9 & 3.3 & 2.4 & & 1.8 \\
\hline \multirow[t]{2}{*}{ Soybean } & $\mathrm{P}_{2} \mathrm{O}_{5}-\mathrm{Lim}$ & 15.5 & 9.7 & 5.6 & 3.7 & 2.6 & & 1.9 \\
\hline & $+\operatorname{Lim}$ & 15.4 & 6.6 & 2.7 & 1.5 & 1.0 & & 0.7 \\
\hline \multirow[t]{2}{*}{ Soybean } & $\mathrm{P}_{2} \mathrm{O}_{5}-\mathrm{Lim}$ & 28.0 & 5.5 & 2.1 & 1.1 & 0.7 & & 0.5 \\
\hline & $+\operatorname{Lim}$ & 37.0 & 8.2 & 3.2 & 1.7 & 1.1 & & 0.7 \\
\hline \multirow[t]{2}{*}{ Wheat } & $\mathrm{P}_{2} \mathrm{O}_{5}-\mathrm{Lim}$ & 5.0 & 4.1 & 3.4 & 2.9 & 2.4 & & 2.1 \\
\hline & $+\operatorname{Lim}$ & 8.3 & 5.7 & 4.0 & 3.0 & 2.3 & & 1.8 \\
\hline \multirow[t]{2}{*}{ Cotton } & $\mathrm{K}_{2} \mathrm{O}-\mathrm{Lim}$ & 10.5 & 2.0 & 0.7 & 0.4 & 0.2 & & 0.2 \\
\hline & $+\operatorname{Lim}$ & 20.8 & 4.0 & 1.5 & 0.8 & 0.5 & & 0.3 \\
\hline
\end{tabular}

${ }^{1}$ Limestone: without (-) or with (+) 4,000 to 7,000 kg/ha; ${ }^{2} \mathrm{Kg}$ of fertilizer/ha $-\mathrm{P}_{2} \mathrm{O}_{5}$ or $\mathrm{K}_{2} \mathrm{O}^{3}{ }^{3} \times 1,000$ $\mathrm{kg} / \mathrm{ha}$ of grain; ${ }^{4} 1$ = Malavolta (1989), p.61, 275 and 283; 2 = Oliveira et al. (1982), p.36; ${ }^{5}$ Considering US $\$ 1.208 / \mathrm{kg}$ of $\mathrm{P}_{2} \mathrm{O}_{5}$ and US $\$ 0.178 / \mathrm{kg}$ of soybean, is necessary $6.8 \mathrm{~kg}$ soybean to pay one $\mathrm{kg}$ of fertilizer. Efficiency lower than $6.8 \mathrm{~kg}$ of soybean $/ \mathrm{kg}$ of $\mathrm{P}_{2} \mathrm{O}_{5}$ is not viable. These calculations can be used to choose the level of fertilization.

Table 2. Changes in the constants of linear regression of the reciprocal of grain production $(x 1,000 \mathrm{~kg} / \mathrm{ha})$ as a function of the reciprocal of amount of fertilizer $(\mathrm{kg} / \mathrm{ha} /$ year $)$, by the second factor, and the respective efficiency of use of fertilizers ( $\mathrm{kg}$ of grains $/ \mathrm{kg}$ of fertilizer)

\section{Marginal response in bovines}

The weight gain in growing bovines in pasture in the dry season is curvilinear as a function of supplement supply, based on corn and soybean meal, in which the supplement conversion (kg of supplement/ $\mathrm{kg}$ of accretion in weight gain) becomes worse with increase in the supplementation (Lana et al., 2005; Keane et al., 2006; Lana, 2007b) (Figure 6).

The milk production by supplemented cows in pasture or in feedlot is also curvilinear as a function of increase in the concentrate supply, based on corn and soybean meal (Figure 7A), in which the marginal increase in milk production per $\mathrm{kg}$ of concentrate decreases with increase in the amount of concentrate (Bargo et al., 2003; Pimentel et al., 2006a; Sairanen et al., 2006; Lana et al., 2007a,b), as shown in Figure 7B, and in some studies the milk response to concentrate was satisfactory only up to $2-4 \mathrm{~kg}$ of concentrate/animal/day (Fulkerson et al., 2006). 
The curvilinear response can also be verified with specific nutrients, such as the observed positive curvilinear response in milk production and negative curvilinear response in the efficiency of use of nitrogen by increasing the dietary crude protein content from 11 to $19 \%$ in cows with mean production of $38 \mathrm{~kg}$ of milk/day (Baik et al., 2006). In the third experiment of Figure 7, in addition to decreasing response in milk production, there was decreasing response in body weight variation with increase in the concentrate level $(0.20$, 0.12 , and $0.095 \mathrm{~kg}$ of body weight gain per additional kilogram of concentrate intake; Teixeira et al., 2006).

\begin{tabular}{|c|c|c|c|c|c|c|c|}
\hline $\begin{array}{c}\text { Fertilizer } \\
\text { (kg/ha/year) }\end{array}$ & Second factor & $\begin{array}{l}\text { Intercept } \\
\text { (a) }\end{array}$ & $\begin{array}{l}\text { Coefficient } \\
\text { (b) }\end{array}$ & $r^{2}$ & $\mathrm{k}_{\mathrm{s}}{ }^{1}$ & $\mathrm{k}_{\max }{ }^{2}$ & $\begin{array}{c}\text { Sorce of } \\
\text { data }^{3}\end{array}$ \\
\hline \multirow{5}{*}{$\mathrm{N}$} & $\mathrm{P}_{2} \mathrm{O}_{5}(\mathrm{~kg} / \mathrm{ha})$ & & & & & & \multirow[t]{5}{*}{ 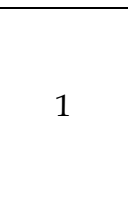 } \\
\hline & 0 & 2.044 & 2.794 & 0.82 & 1 & 0.5 & \\
\hline & 40 & 0.782 & 8.516 & 1.00 & 11 & 1.3 & \\
\hline & 80 & 0.710 & 6.718 & 0.99 & 9 & 1.4 & \\
\hline & 100 & 0.630 & 8.205 & 1.00 & 13 & 1.6 & \\
\hline \multirow{5}{*}{$\mathrm{N}$} & $\mathrm{P}_{2} \mathrm{O}_{5}(\mathrm{~kg} / \mathrm{ha})$ & & & & & & \multirow{5}{*}{2} \\
\hline & 0 & 10.764 & 183.36 & 0.23 & 17 & 0.1 & \\
\hline & 50 & 2.5229 & 46.235 & 0.78 & 18 & 0.4 & \\
\hline & 150 & 1.3364 & 15.623 & 0.99 & 12 & 0.7 & \\
\hline & 250 & 0.9539 & 28.056 & 0.98 & 29 & 1.0 & \\
\hline \multirow{4}{*}{$\mathrm{P}_{2} \mathrm{O}_{5}$} & $\mathrm{~N}$ (kg/ha) & & & & & & \multirow{4}{*}{1} \\
\hline & 0 & 1.3812 & 6.7411 & 0.98 & 5 & 0.7 & \\
\hline & 30 & 0.8181 & 8.8241 & 1.00 & 11 & 1.2 & \\
\hline & 60 & 0.6842 & 10.186 & 1.00 & 15 & 1.5 & \\
\hline \multirow{4}{*}{$\mathrm{P}_{2} \mathrm{O}_{5}$} & $\mathrm{~N}$ (kg/ha) & & & & & & \multirow{4}{*}{2} \\
\hline & 0 & 1.3257 & 180.38 & 0.95 & 136 & 0.8 & \\
\hline & 50 & 1.0402 & 90.586 & 1.00 & 87 & 1.0 & \\
\hline & 120 & 0.6684 & 132.74 & 1.00 & 199 & 1.5 & \\
\hline
\end{tabular}

${ }^{1} \mathrm{Kg}$ of fertilizer/ha; ${ }^{2}$ Ton of grain/ha; ${ }^{3} 1$ = Bolsanello et al. (1975) and Oliveira et al. (1982), p.155; 2 = Malavolta (1989), p.273.

Table 3. Changes in constants of linear regression of reciprocal of bean production $(x 1,000$ $\mathrm{kg} / \mathrm{ha}$ ) as a function of reciprocal of amount of fertilizer ( $\mathrm{kg} / \mathrm{ha} /$ year), by a second factor

According to the Biotechnology and Biological Sciences Research Council (1998), formerly known as AFRC (Agricultural and Food Research Council), all currently feed systems calculate the dietary requirements of energy and protein to meet the animals needs for maintenance and production. However, in practice, the situation is different, because there is no need for the farmer to meet the cow's nutritional requirements if it is against the economical interest. So, it is evident that studies in animal response to increasing levels of concentrate or specific nutrients are needed, as suggested by Lana (2003; p.87).

Although the animal's responses to nutrients are curvilinear, the daily weight gains estimated by the level 1 of NRC (1996) of beef cattle are linear as a function of intakes of metabolizable energy and protein (Figure 8A). In the same way, the milk production estimated by the model CNCPS 5.0 as a function of intakes of metabolizable energy and protein, and model NRC (2001) of dairy cattle as a function of intakes of net energy for lactation and metabolizable protein, were linear by using increasing levels of concentrate 


\begin{tabular}{|c|c|c|c|c|c|c|c|}
\hline \multirow{2}{*}{$\begin{array}{c}\text { Fertilizer } \\
(\mathrm{kg} / \mathrm{ha})\end{array}$} & \multirow{2}{*}{$\begin{array}{l}\text { Second } \\
\text { factor }\end{array}$} & \multicolumn{6}{|c|}{ Efficiency of use of fertilizers ( $\mathrm{kg}$ of grains $/ \mathrm{kg}$ of fertilizer) ${ }^{1}$} \\
\hline & & $50^{2}$ & 100 & 150 & 200 & 250 & 300 \\
\hline \multirow{5}{*}{$\mathrm{N}$} & $\begin{array}{c}\mathrm{P}_{2} \mathrm{O}_{5} \\
\text { (kg/ha) }\end{array}$ & & & & & & \\
\hline & 0 & 1.1 & 0.1 & 0.0 & 0.0 & 0.0 & 0.0 \\
\hline & 40 & 10.9 & 2.1 & 0.8 & 0.4 & 0.3 & 0.2 \\
\hline & 80 & 11.5 & 2.0 & 0.8 & 0.4 & 0.2 & 0.2 \\
\hline & 100 & 14.2 & 2.9 & 1.1 & 0.6 & 0.4 & 0.3 \\
\hline \multirow{5}{*}{$\mathrm{N}$} & $\begin{array}{c}\mathrm{P}_{2} \mathrm{O}_{5} \\
\text { (kg/ha) }\end{array}$ & & & & & & \\
\hline & 0 & 0.6 & 0.2 & 0.1 & 0.0 & 0.0 & 0.0 \\
\hline & 50 & 2.8 & 0.9 & 0.4 & 0.2 & 0.1 & 0.1 \\
\hline & 150 & 4.5 & 1.3 & 0.5 & 0.3 & 0.2 & 0.1 \\
\hline & 250 & 7.9 & 3.0 & 1.3 & 0.7 & 0.5 & 0.3 \\
\hline \multirow{4}{*}{$\mathrm{P}_{2} \mathrm{O}_{5}$} & $\begin{array}{c}\mathrm{N} \\
(\mathrm{kg} / \mathrm{ha})\end{array}$ & & & & & & \\
\hline & 0 & 5.4 & 0.6 & 0.2 & 0.1 & 0.1 & 0.0 \\
\hline & 30 & 12.2 & 2.0 & 0.7 & 0.4 & 0.2 & 0.2 \\
\hline & 60 & 15.3 & 2.9 & 1.1 & 0.6 & 0.4 & 0.3 \\
\hline \multirow{5}{*}{$\mathrm{P}_{2} \mathrm{O}_{5}$} & $\mathrm{~N}$ & & & & & & \\
\hline & (kg/ha) & & & & & & \\
\hline & 0 & 4.0 & 2.3 & 1.5 & 1.1 & 0.8 & 0.6 \\
\hline & 50 & 6.9 & 3.3 & 1.9 & 1.2 & 0.9 & 0.6 \\
\hline & 120 & 6.0 & 4.0 & 2.9 & 2.1 & 1.7 & 1.3 \\
\hline
\end{tabular}

${ }^{1}$ Considering US $\$ 0.966 / \mathrm{kg}$ of N, US\$1.208/ $\mathrm{kg}$ of $\mathrm{P}_{2} \mathrm{O}_{5}$ and US $\$ 0.36 / \mathrm{kg}$ of bean, it is necessary 2.68 and $3.36 \mathrm{~kg}$ of bean to pay $1 \mathrm{~kg}$ of $\mathrm{N}$ or $\mathrm{P}_{2} \mathrm{O}_{5}$. Efficiency worse than 2.68 or $3.36: 1$ for $\mathrm{N}$ or $\mathrm{P}_{2} \mathrm{O}_{5}$ is not economically desirable. These calculations can be used to choose the level of fertilization. ${ }^{2}$ Level of fertilizer (kg/ha) - $\mathrm{N}$ in the first two cases or $\mathrm{P}_{2} \mathrm{O}_{5}$ in the last two cases.

Table 4. Efficiency of use of fertilizers ( $\mathrm{kg}$ of bean/ $\mathrm{kg}$ of fertilizer) calculated with base in the equations of Table 3
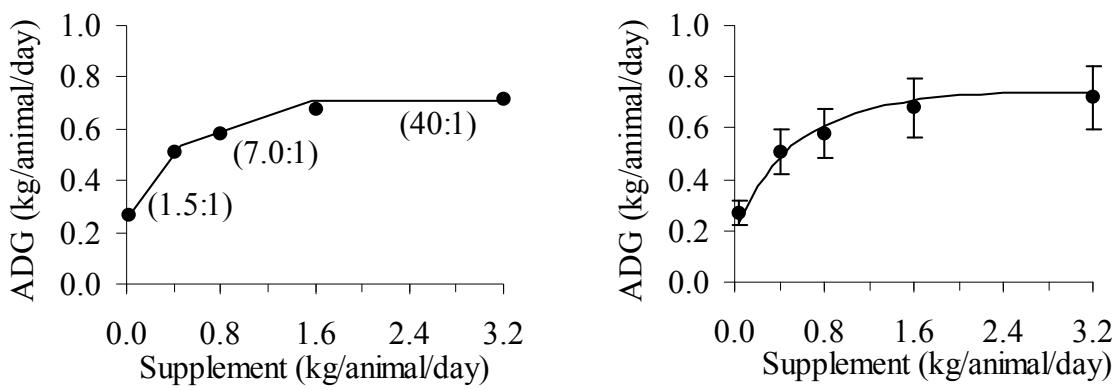

Fig. 6. Body weight gain (BWG) of growing bovines in pasture during the dry season, as a function of daily intake of supplement with $24 \% \mathrm{CP}$, in which the values among parenthesis represent the differential in kilograms of supplement given daily divided by the differential in weight gain, in relation to the previous treatment (Lana, 2005; Lana et al., 2005) 
(Figure 8B), as suggested by Lana (2005; p.290-291) and Lana (2007b; p.39 a 43). Therefore, in order to these systems be compatible with the tropical conditions, in which it is more evident the curvilinear responses to nutrients, it is necessary modifications in future versions, by adopting models of saturation kinetics.

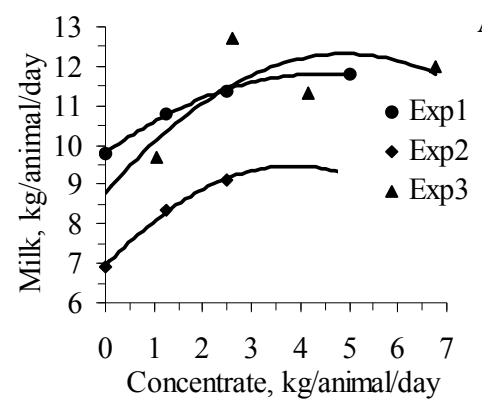

A

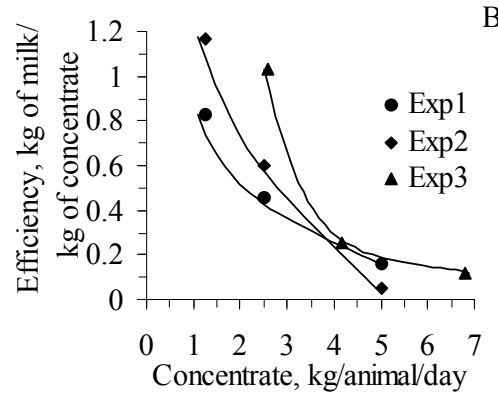

Fig. 7. Production of milk (A) and efficiency of use of concentrate (B) as a function of intake of increasing level of concentrate in three experiments (Pimentel et al., 2006b, 2006c; Teixeira et al., 2006)

\section{Production versus productivity}

Two studies were conducted to evaluate the factors that affect milk production in Brazil, on farmer level or by state of federation (Guimarães et al., 2008; Lana et al., 2009). In the first case, data were collected from fifty producers that sell milk for a dairy plant in the south region of Rio de Janeiro state, including data of daily milk production by producer, with the respective data of production per cow and per hectare, farmer size and size area designated to the herd, total of milking cows and herd size, and breed (Table 5). In the second case, data were collected from EMBRAPA and IBGE in the years of 2004-2006, in which the emphasis was in milk production per state instead of production per producer.
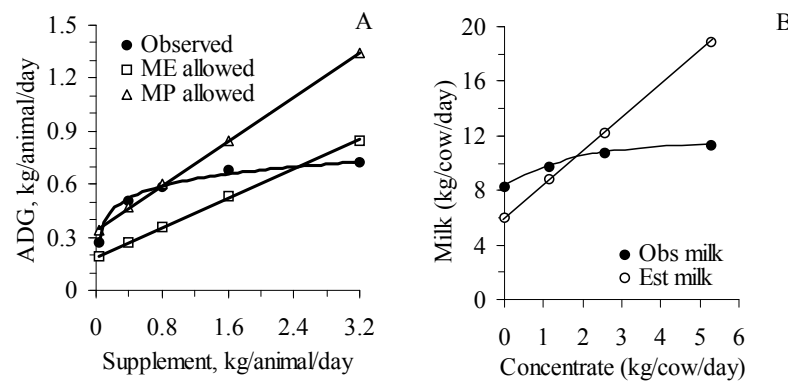

Fig. 8. Mean daily weight gain of steers in pastures, observed and estimated by level 1 of NRC (1996) as a function of intake of metabolizable energy and protein in the supplement (A); and observed milk production (mean of data of Figure 7A) and estimated by CNCPS 5.0 and NRC (2001) as a function of intakes of metabolizable energy or net energy of lactation, respectively, and metabolizable protein (B) 


\begin{tabular}{|c|c|c|c|c|c|}
\hline $\begin{array}{l}\text { Production } \\
\text { (Kg of milk/ } \\
\text { producer/day) }\end{array}$ & $\begin{array}{l}\text { Number } \\
\text { of } \\
\text { producers }\end{array}$ & $\begin{array}{c}\text { Production } \\
\text { per producer } \\
\text { (Kg of } \\
\text { milk/day) }\end{array}$ & $\begin{array}{l}\text { Area for the } \\
\text { herd } \\
\text { (ha) }\end{array}$ & $\begin{array}{c}\text { Herd } \\
\text { (number of } \\
\text { animals) }\end{array}$ & $\begin{array}{l}\text { Milking } \\
\text { cows } \\
\text { (number) }\end{array}$ \\
\hline Up to 150 & 6 & 117 & 37 & 56 & 14 \\
\hline $151-300$ & 12 & 238 & 70 & 73 & 28 \\
\hline $301-600$ & 14 & 451 & 106 & 94 & 43 \\
\hline $601-1200$ & 14 & 821 & 111 & 159 & 66 \\
\hline $1201-2400$ & 3 & 1667 & 316 & 633 & 132 \\
\hline $2401-4800$ & 1 & 4000 & 300 & 1800 & 300 \\
\hline $\begin{array}{l}\mathrm{Kg} \text { of milk/ } \\
\text { producer/day }\end{array}$ & $\begin{array}{l}\text { Milking } \\
\text { cows/ha }\end{array}$ & $\begin{array}{c}\text { Milk } \\
(\mathrm{Kg} / \mathrm{ha} / \text { day })\end{array}$ & $\begin{array}{c}\text { Milk } \\
\text { (Kg/milking } \\
\text { cow/day) }\end{array}$ & $\begin{array}{c}\text { Milk } \\
\text { (Kg/total } \\
\text { herd/day) }\end{array}$ & $\begin{array}{c}\text { Milking } \\
\text { cows/total } \\
\text { herd }\end{array}$ \\
\hline Up to 150 & 0.38 & 3.17 & 8.33 & 2.08 & 0.25 \\
\hline $151-300$ & 0.40 & 3.40 & 8.57 & 3.27 & 0.38 \\
\hline $301-600$ & 0.41 & 4.27 & 10.53 & 4.77 & 0.45 \\
\hline $601-1200$ & 0.59 & 7.41 & 12.51 & 5.15 & 0.41 \\
\hline $1201-2400$ & 0.42 & 5.27 & 12.66 & 2.63 & 0.21 \\
\hline $2401-4800$ & 1.00 & 13.33 & 13.33 & 2.22 & 0.17 \\
\hline
\end{tabular}

Table 5. Number of producers, daily mean milk production by producer, area for the herd, number of animals and milking cows in the herd, and productivity indexes per area and per cow, as a function of production levels

The milk production in farmer level (first case) ranged from 60 to $4000 \mathrm{~kg} /$ producer/day. The increase in milk production was highly correlated with the number of milking cows $(\mathrm{r}=$ 0.94), followed by moderate correlation with the size of pasture $(r=0.67)$ and, surprisingly, the productivity per cow and per unit of area did not correlate with the milk production per producer $(r=0.11$ and 0.06 , respectively; Table 6$)$. In the nation level (second case), the result repeated, in which there was high correlation of milk production/state/year with the total of milking cows in relation to productivity of milk $/ \mathrm{km}^{2} /$ year and milk $/ \mathrm{cow} /$ year $(\mathrm{r}=0.95$, 0.55 and 0.51 , respectively; Table 7).

\begin{tabular}{cccc}
\hline Parameter & Correlation $(\mathrm{r})$ & Parameter & Correlation $(\mathrm{r})$ \\
\hline Total animals in the & 0.94 & Milk $(\mathrm{kg} / \mathrm{ha})$ & 0.13 \\
herd & 0.93 & Milk $(\mathrm{kg} / \mathrm{cow} /$ day $)$ & 0.11 \\
Total milking cows & 0.67 & Milking cows $/ \mathrm{ha}$ & 0.06 \\
Area for the herd $(\mathrm{ha})$ & 0.20 & Milk $(\mathrm{kg} /$ total of & -0.11 \\
Total area in the farm & animals/day) & \\
\hline
\end{tabular}

Table 6. Linear correlation of daily milk production by producer with: total of animals in the herd, total of milking cows, area for the herd, farmer size and some productivity indexes (daily milk production per hectare and per cow, milking cows per hectare and daily milk production per total animals in the herd)

Therefore, the milk production by Brazilian farmers is more dependent on the farmer size and pasture extension, than on productivity indexes, and similar effect occur with crop production (Lana, 2009). Agricultural showed the same results verified with dairy cattle, in 
which cultivated area generally presents more than $90 \%$ correlation with crop production (Table 8 and Figure 9). Then, the concepts about agricultural production need to be revised, facing the actual problems related with the inadequate use and depletion of the non renewable natural resources, and environmental pollution.

\begin{tabular}{ccccc}
\hline Parameters & $\begin{array}{c}\text { Liters of } \\
\text { milk/state/year }\end{array}$ & $\begin{array}{c}\text { Total of } \\
\text { milked cows }\end{array}$ & $\begin{array}{c}\text { Liters of } \\
\text { milk } / \mathrm{km}^{2} / \text { year }\end{array}$ & $\begin{array}{c}\text { Liters of } \\
\text { milk/cow/year }\end{array}$ \\
\hline $\begin{array}{c}\text { Total of milking } \\
\text { cows }\end{array}$ & 0.95 & & & \\
$\begin{array}{c}\text { Liters of } \\
\text { milk } / \mathrm{km}^{2} / \text { year } \\
\text { Liters of }\end{array}$ & 0.55 & 0.39 & & \\
$\begin{array}{c}\text { milk/cow } / \text { year } \\
\text { Surface of state } \\
\left.\text { (in } \mathrm{km}^{2}\right)\end{array}$ & 0.51 & 0.31 & 0.88 & -0.26 \\
\hline
\end{tabular}

Table 7. Linear correlation (r) of annual milk production by Brazilian states with total of milked cows, liters of milk/ $\mathrm{km}^{2} /$ year, liters of milk/cow/year and surface of the state (in $\left.\mathrm{km}^{2}\right)$.

\begin{tabular}{ccccc}
\hline Item & $\mathrm{n}$ & $\begin{array}{c}\text { Production } \\
\text { (ton/year) } \\
\text { X planted area (ha) }\end{array}$ & $\begin{array}{c}\text { Production (ton/year) } \\
\text { X productivity } \\
\text { (ton/ha) }\end{array}$ & $\begin{array}{c}\text { productivity } \\
\text { (ton/ha) }\end{array}$ \\
X planted area (ha) \\
\hline Corn & 110 & 0.95 & 0.35 & 0.14 \\
Bean $^{1 \mathrm{a}}$ & 110 & 0.87 & 0.18 & 0.02 \\
Bean $^{\mathrm{b}}$ & 110 & 0.96 & 0.42 & 0.31 \\
Sugarcane $^{\mathrm{t}}$ & 101 & 0.99 & 0.34 & 0.30 \\
Coffee & 95 & 0.98 & 0.07 & 0.00 \\
Banana $^{2}$ & 90 & 0.96 & -0.02 & -0.14 \\
Cassava & 86 & 0.98 & 0.21 & 0.09 \\
Orange $^{3}$ & 84 & 0.91 & 0.32 & 0.03 \\
Rice $^{4 \mathrm{a}}$ & 76 & 0.88 & 0.22 & -0.05 \\
Rice $^{4 \mathrm{~b}}$ & 71 & 0.91 & 0.53 & 0.38 \\
Tomato $_{\text {Coconut }}$ & 51 & 0.98 & 0.46 & 0.37 \\
Potato $^{5 \mathrm{a}}$ & 18 & 0.95 & 0.31 & 0.12 \\
Potato $^{5 \mathrm{~b}}$ & 11 & 0.99 & 0.47 & 0.42 \\
Potato $^{\mathrm{c}}$ & 10 & 0.88 & 0.22 & -0.19 \\
\hline Mean & & 0.99 & -0.20 & -0.29 \\
\hline
\end{tabular}

Source: Lana \& Guimarães (2010); $\mathrm{n}=$ number of municipalities; $1 \mathrm{a}=$ first harvest; $1 \mathrm{~b}=$ mean of second and third harvest; $2=$ racemes instead of ton $(1,000 \mathrm{~kg}) ; 3=$ number $(x 1000)$ of oranges instead of ton $(1,000 \mathrm{~kg}) ; 4 \mathrm{a}=$ rice planted in wet land; $4 \mathrm{~b}=$ rice planted in dry land, without or with irrigation; $5 \mathrm{a}, \mathrm{b}, \mathrm{c}$ $=$ harvest 1, 2 and 3, respectively; Source of data: www.cidadesnet.com.br (year of 2003).

Table 8. Linear correlation (r) among some variables related to agricultural production, in municipalities of Zona da Mata and Central of Minas Gerais state, Brazil. 


\section{Conclusions}

The agriculture progress is based in improvements of animals and plants productivity per unit of area, which is only applicable when land is the limiting factor, but other factors are emerging as limiting, such as water, fertilizer and petrol.

Models of saturation kinetics are important tools to improve the efficiency and decrease costs of utilization of non renewable natural resources in agriculture, allowing the conservation of these resources for the future generations, and decreasing the negative impacts in the environment.
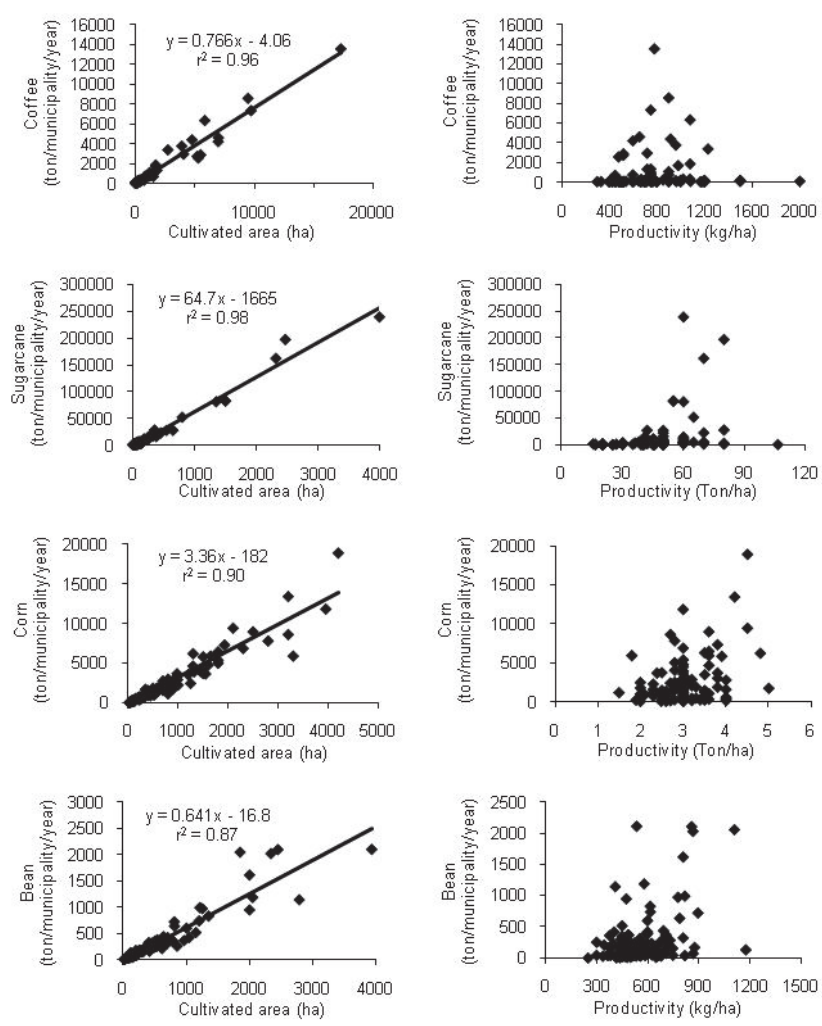

Fig. 9. Effect of cultivated area and productivity on production of some main cultures (coffee, sugarcane, corn and bean), in municipalities of Zona da Mata and Central of Minas Gerais state, Brazil.

\section{References}

Aaron, S. (2005). Some Statistics on Limited Natural Resources, 31.07.2006, available from Http://scotaaron.com/resources2.html

Angus, J.F. (1995). Modeling N Fertilization Requirements for Crops and Pasture, In: Nitrogen Fertilization in the Environment, P.E. Bacon, (Ed.), 109-127, Marcel Dekker inc., ISBN 0-8247-8994-6, New York, NY, United States 
Baik, M.; Aschenbach, J.R.; Vandehaar, M.J. \& Liesman, J.S. (2006). Effect of Dietary Protein Levels on Milk Production and Nitrogen Efficiency in Dairy Cattle. Journal of Dairy Science, Vol.89, Suppl. 1, pp.81, ISSN 0022-0302

Bargo, F.; Muller, L.D.; Kolver, E.S. \& Delahoy, J.E. (2003) Invited Review: Production and Digestion of Supplemented Dairy Cows on Pasture. Journal of Dairy Science, Vol.86, No.1, pp.1-42, ISSN 0022-0302

Biotechnology and Biological Sciences Research Council (1998). Responses in the Yield of Milk Constituents to the Intake of Nutrients by Dairy Cows, CAB International, ISBN 0-85199284-6, Wallingford, United Kingdon

Bolsanello, J.; Vieira, C.; Sediyama, C.S. \& Vieira, H.A. (1975). Ensaios de Adubação Nitrogenada e Fosfatada no Feijão (Phaseolus vulgaris L.) na Zona Metalúrgica de Minas Gerais. Revista Ceres, Vol.22, pp.423-430, ISSN 0034-737X

Bullock, D.G. \& Bullock, D.S. (1994). Quadratique and Quadratic-Plus-Plateau Models for Predicting Optimal N Rate for Corn. A comparison. Agronomy Journal, Vol.86, pp.191-195, ISSN 1435-0645

Bumb, B.L. (1995). World Nitrogen Supply and Demand: an Overview, In: Nitrogen Fertilization in the Environment, P.E. Bacon, (Ed.), 1-40, Marcel Dekker inc., ISBN 08247-8994-6, New York, NY, United States

Cerrato, M.E. \& Blackmer, A.M. (1990). Comparison of Models for Describing Corn Yield Response to Nitrogen Fertilizer. Agronomy Journal, Vol.82, pp.138-143, ISSN 1435-0645

Champe, P.C. \& Harvey, R.A. (1994). Biochemistry, J.B. Lippincott Company, ISBN 0-39751091-8, Philadelphia, PA, United States

Fulkerson, W.J.; Nandra, K.S.; Clark, C.F. \& Barchia, I. (2006). Effect of Cereal-Based Concentrates on Productivity of Holstein-Friesian Cows Grazing Short-Rotation Ryegrass (Lolium multiflorum) or Kikuyu (Pennesitum clandestinum) Pastures. Livestock Science, Vol.103, pp.85-94, ISSN 1871-1413

Granli, T. \& Bockman, O.C. (1994). Nitrogen Oxide from Agriculture. Norwegian Journal of Agricultural Sciences, Vol.12, pp.7-127, ISSN 0801-5341

Guimarães, G.; Lana, R.P.; Guimarães, A.V.; Santos, M.A.; Andrade, F.L.; Fialho, C. \& Castro, T.R. (2008). Sustentabilidade da Agricultura Familiar na Produção de Leite, Proceedings of $10^{\circ}$ Minas Leite, EMBRAPA, CDD 637.1, Juiz de Fora, MG, Brazil

Helyar, K.R.; Poter, W.M. (1989). Soil Acidification, its Measurement and the Processes Involved, In: Soil acidity and plant growth, A.D. Robson, (Ed.), 61-100, Academic Press, ISBN 0-1259-0655-2, Sydney, Australia

Herring, J.R. \& Fantel, R.J. (1993). Phosphate Rock Demand into the Next Century: Impact on World Food Supply. Nonrenewable Resources, Vol.2, No.3, pp.226-246, ISSN 0961-1944

Keane, M.G.; Drennan, M.J. \& Moloney, A.P. Comparison of Supplementary Concentrate Levels with Grass Silage, Separate or Total Mixed Ration Feeding, and Duration of Finishing in Beef Steers. Livestock Science, Vol.103, pp.169-180, ISSN 1871-1413

Kebreab, E.; France, J.; Mills, J.A.N.; Allison, R. \& Dijkstra, J. (2002). A Dynamic Model of N Metabolism in the Lactating Cow and an Assessment of Impact on $\mathrm{N}$ Excretion on the Environment. Journal of Animal Science, Vol.80, pp.248-259, ISSN 0021-8812

Lana, R.P. (2003). Sistema Viçosa de Formulação de Rações, Editora UFV, ISBN 978-85-7269-3141, Viçosa, MG, Brazil

Lana, R.P. (2005). Nutrição e Alimentação Animal (Mitos e Realidades), Suprema Gráfica, ISBN 978-85-9050-672-0, Viçosa, MG, Brazil

Lana, R.P. (2007a). Plants Responses to Nutrients Follow a Michaelis-Menten Relationship, Proceedings of ASA, CSSA, SSSA International Annual Meetings, ASA-CSSA-SSSA, ISSN 1529-9163, New Orleans, United States 
Lana, R.P. (2007b). Respostas Biológicas aos Nutrientes, Editora CPD, ISBN 978-85-9050-673-7, Viçosa, MG, Brazil

Lana, R.P. (2008). Plants Responses to Nutrients Follow the Saturation Kinetic Typical of Enzyme Systems: Biological, Economical and Environmental Implications. Online Journal of Biological Sciences, Vol.8, No.1, pp.19-24, ISSN 1608-4217

Lana, R.P. (2009). Uso Racional de Recursos Naturais não Renováveis: Aspectos Biológicos, Econômicos e Ambientais. Revista Brasileira de Zootecnia, Vol.38, pp.330-340, Supplement Especial, ISSN 1806-9290

Lana, R.P.; Abreu, D.C.; Castro, P.F.C. \& Zamperline, B. (2007a). Milk Production as a Function of Energy and Protein Sources Supplementation Follows the Saturation Kinetics Typical of Enzyme Systems, Proceedings of $2^{\text {nd }}$ International Symposium on Energy and Protein Metabolism and Nutrition, European Association for Animal Production, ISBN 978-90-8686-041-8, Vichy, France

Lana, R.P.; Abreu, D.C.; Castro, P.F.C.; Zamperlini, B. \& Souza, B.S.B.C. (2007b). Kinetics of Milk Production as a Function of Energy and Protein Supplementation. Journal of Animal Science, Vol.85, Suppl. 1, pp.566, ISSN 0021-8812

Lana, R.P.; Goes, R.H.T.B.; Moreira, L.M.; Mancio, A.B. \& Fonseca, D.M. (2005). Application of Lineweaver-Burk Data Transformation to Explain Animal and Plant Performance as a Function of Nutrient Supply. Livestock Production Science, Vol.98, pp.219-224, ISSN 0301-6226

Lana, R.P.; Guimarães, G.; Guimarães, A.V. \& Santos, M.A. (2009). Factors Affecting Milk Production in Brazil. Journal of Dairy Science, Vol.92, Suppl. 1, pp.427, ISSN 0022-0302

Lana, R.P. \& Guimarães, G. (2010). Produção Média e Correlações entre Algumas Variáveis que Afetam a Produção de Diversas Culturas em Municípios da Zona da Mata e Central de Minas Gerais, In: $2^{\circ}$ Simpósio Brasileiro de Agropecuária Sustentável - Anais de Resumos Expandidos, R.P. Lana \& G. Guimarães, (Eds.), ISSN 2176-0772, Viçosa, MG, Brazil

Lemke, R.L.; Izaurralde, R.C.; Malhi, S.S.; Arshad, M.A. \& Nyborg, M. (1998). Nitrous Oxide Emissions from Agricultural Soils of the Boreal and Parkland Regions of Alberta. Soil Science Society of America Journal, Vol.62, pp.1096-1102, ISSN 0361-5995

Lineweaver, H. \& Burk, D. (1934). The Determination of Enzyme Dissociation Constants. Journal of the American Chemical Society, Vol.56, pp.658-666, ISSN 0002-7863

Makowski, D.; Wallach, D. \& Meynard, J.-M. (1999). Model of Yield, Grain Protein, and Residual Mineral Nitrogen Responses to Applied Nitrogen for Winter Wheat. Agronomy Journal, Vol.91, pp.377-385, ISSN 1435-0645

Makowski, D.; Wallach, D. \& Meynard, J.-M. (2001). Statistical Methods for Predicting Responses to Applied Nitrogen and Calculating Optimal Nitrogen Rates. Agronomy Journal, Vol.93, pp.531-539, ISSN 1435-0645

Meadows, D.H.; Meadows, D.L.; Randers, J. \& Behrens III, W.W. (1972). The Limits of Growth. A Report for the Club of Rome's Project on the Predicament of Mankind, Universe Books, ISBN 0-87663-165-0, New York, NY, United States

Michaelis, L. \& Menten, M.L. (1913). Kinetics of Invertase Action. Biochemistry Zournal, Vol.49, pp.333-369, ISSN 1470-8728

Mitscherlich, E.A. (1909). Das Gesetz des Minimuns und das Gesetz des Abnehmenden Bodenertrages. Landwirtschaftliches Jahrbuch, Vol.38, pp.537-552, ISSN 0005-7150

Malavolta, E. (1989). ABC da Adubação, Editora Ceres, ISBN 85-318-0002-1, São Paulo, SP, Brazil

Mombiela, F.; Nicholaides III, J.J. \& Nelson L.A. (1981). A Method to Determine the Appropriate Mathematical form for Incorporating Soil Test Levels in Fertilizer Response Models for Recommendation Purposes. Agronomy Journal, Vol.73, pp.937941, ISSN 1435-0645 
Monod, J. (1949). The Growth of Bacterial Cultures. Annual Review of Microbiology, Vol.3, pp.371-394, ISSN 0066-4227

Morgan, H.P.; Mercer, L.P. \& Flodin, N.W. (1975). General Model for Nutritional Responses of Higher Organisms. Proceedings of the National Academy of Sciences, Vol.72, No.11, pp.4327-4331, ISSN 0027-8424

NRC. Nutrient Requirements of Beef Cattle. (1996). National Academy Press, ISBN 0-309-069343, Washington, DC, United States

NRC. Nutrient Requirements of Dairy Cattle. (2001). National Academy Press, ISBN 0-30906997-1, Washington, DC, United States

Oliveira, A.J.; Lourenço, S. \& Goedert, W.J. (1982). Adubação Fosfatada no Brasil, EMBRAPADID, CDD 631.850981, Brasília, DF, Brazil

Pimentel, J.J.O.; Lana, R.P.; Zamperlini, B.; Paulino, M.F.; Valadares Filho, S.C.; Teixeira, R.M.A. \& Abreu, D.C. (2006a). Milk Production as a Function of Nutrient Supply Follows a Michaelis-Menten Relationship. Journal of Dairy Science, Vol.89, Suppl. 1, pp.74-75, ISSN 0022-0302

Pimentel, J.J.O.; Lana, R.P.; Zamperlini, B.; Valadares Filho, S.C.; Abreu, D.C.; Silva, J.C.P.M. \& Souza, B.S.B.C. (2006b). Efeito do Teor de Proteína e Níveis de Suplementação com Concentrado na Produção e Composição do Leite em Vacas Leiteiras Confinadas, Proceedings of $43^{a}$ Reunião Anual da Sociedade Brasileira de Zootecnia, Sociedade Brasileira de Zootecnia, ISSN 1983-4357, João Pessoa, PB, Brazil

Pimentel, J.J.O.; Lana, R.P.; Teixeira, R.M.A.; Zamperlini, B.; Sobreira, H.F.; Paulino, M.F.; Leão, M.I. \& Oliveira, A.S. (2006c). Produção de Leite em Função de Níveis de Suplementação com Concentrado para Vacas Leiteiras sob Pastejo, Proceedings of $43^{a}$ Reunião Anual da Sociedade Brasileira de Zootecnia, Sociedade Brasileira de Zootecnia, ISSN 1983-4357, João Pessoa, PB, Brazil

Roberts, T.L. \& Stewart, W.M. (2002). Inorganic Phosphorus and Potassium Production and Reserves. Better Crops, Vol.86, No.2, pp.6-7, ISSN 0006-0089

Russell, J.B. (1984). Factors Influencing Competition and Composition of the Ruminal Bacterial Flora, In: The Herbivore Nutrition in the Subtropics and Tropics, F.M.C. Gilchrist \& R.I. Mackie, (Eds.), 313-345, Science Press, ISBN 10 0907997031, Craighall, South Africa

Russell, J.B. (2002). Rumen Microbiology and its Role in Ruminant Nutrition, James B. Russell, Ithaca, NY, United States

Sain, G.E. \& Jauregui, M.A. (1993). Deriving Fertilizer Recommendations with a Flexible Functional Form. Agronomy Journal, Vol.85, pp.934-937, ISSN 1435-0645

Sairanen, A.; Khalili, H. \& Virkajarvi, P. (2006). Concentrate Supplementation Responses Of The Pasture-Fed Dairy Cow. Livestock Science, Vol.104, No.3, pp.292-302, ISSN 1871-1413

Strong, W.M. (1995). Nitrogen fertilization of upland crops, In: Nitrogen Fertilization in the Environment, P.E. Bacon, (Ed.), 129-169, Marcel Dekker inc., ISBN 0-8247-8994-6, New York, NY, United States

Teixeira, R.M.A; Lana, R.P.; Fernandes, L.O.; Veloso, R.G.; Ferreira, M.B.D. \& Paiva, V.R. (2006). Efeito da Adição de Concentrado em Dietas de Vacas Gir Leiteiro Confinadas sob a Produção de Leite, Proceedings of $43^{a}$ Reunião Anual da Sociedade Brasileira de Zootecnia, Sociedade Brasileira de Zootecnia, ISSN 1983-4357, João Pessoa, PB, Brazil.

Van Der Ploeg, R.R.; Böhm, W. \& Kirkham, M.B. (1999). On the Origin of the Theory of Mineral Nutrition of Plants and the Law of the Minimum. Soil Science Society of America Journal, Vol.63, pp.1055-1062, ISSN 0361-5995 


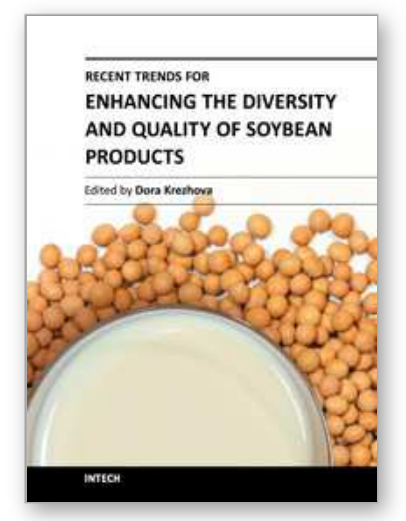

\author{
Recent Trends for Enhancing the Diversity and Quality of Soybean \\ Products \\ Edited by Prof. Dora Krezhova
}

ISBN 978-953-307-533-4

Hard cover, 536 pages

Publisher InTech

Published online 28, October, 2011

Published in print edition October, 2011

This book presents new aspects and technologies for the applicability of soybean and soybean products in industry (human food, livestock feed, oil and biodiesel production, textile, medicine) as well as for future uses of some soybean sub-products. The contributions are organized in two sections considering soybean in aspects of food, nutrition and health and modern processing technologies. Each of the sections covers a wide range of topics. The authors are from many countries all over the world and this clearly shows that the soybean research and applications are of global significance.

\title{
How to reference
}

In order to correctly reference this scholarly work, feel free to copy and paste the following:

Rogério de Paula Lana (2011). Rationality in the Use of Non Renewable Natural Resources in Agriculture, Recent Trends for Enhancing the Diversity and Quality of Soybean Products, Prof. Dora Krezhova (Ed.), ISBN: 978-953-307-533-4, InTech, Available from: http://www.intechopen.com/books/recent-trends-for-enhancingthe-diversity-and-quality-of-soybean-products/rationality-in-the-use-of-non-renewable-natural-resources-inagriculture

\section{INTECH}

open science | open minds

\section{InTech Europe}

University Campus STeP Ri Slavka Krautzeka 83/A 51000 Rijeka, Croatia Phone: +385 (51) 770447

Fax: +385 (51) 686166 www.intechopen.com

\section{InTech China}

Unit 405, Office Block, Hotel Equatorial Shanghai No.65, Yan An Road (West), Shanghai, 200040, China 中国上海市延安西路65号上海国际贵都大饭店办公楼405单元 Phone: +86-21-62489820

Fax: +86-21-62489821 
(C) 2011 The Author(s). Licensee IntechOpen. This is an open access article distributed under the terms of the Creative Commons Attribution 3.0 License, which permits unrestricted use, distribution, and reproduction in any medium, provided the original work is properly cited. 